\title{
Roseibacterium elongatum gen. nov., sp. nov., an aerobic, bacteriochlorophyll-containing bacterium isolated from the west coast of Australia
}

Correspondence

Tomonori Suzuki

chijun@rs.noda.tus.ac.jp

\author{
Tomonori Suzuki, Youichirou Mori and Yukimasa Nishimura
}

Department of Applied Biological Science, Tokyo University of Science, 2641, Yamazaki, Noda, Chiba 278-8510, Japan

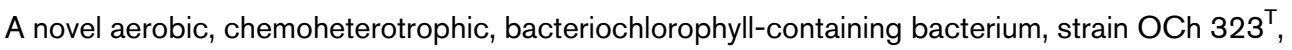
was isolated from sand at Monkey Mia, Shark Bay, located on the west coast of Australia. The cells were Gram-negative, non-motile rods of variable length; one or both cell poles was narrower. Bacteriochlorophyll a was synthesized under aerobic conditions. Catalase, oxidase and urease were produced. The ONPG reaction was positive. The major component of the cellular fatty acid was octadecenoic acid (18:1). The DNA G+C content was $68 \cdot 1 \mathrm{~mol} \%$. The results of $16 \mathrm{~S}$ rRNA gene sequence comparisons revealed that strain $\mathrm{OCh} 323^{\top}$ formed a novel, separate line of descent within the $\alpha-3$ group of the Alphaproteobacteria. The similarity value for the $16 \mathrm{~S}$ rRNA gene sequence of strain $\mathrm{OCh} 323^{\top}$ and that of the most closely related species, Rhodovulum sulfidophilum, was $91.4 \%$. It is concluded that strain OCh $323^{\top}$ (= JCM $11220^{\top}=$ CIP $107377^{\top}$ ) should be placed in a novel genus, Roseibacterium gen. nov., as the type strain of a novel species Roseibacterium elongatum sp. nov.
\end{abstract}

Since Sato (1978) reported on aerobic methylotrophs containing bacteriochlorophyll $a$, a variety of aerobic, anoxygenic, phototrophic bacteria have been described (Yurkov \& Beatty, 1998). Recently, many novel genera of aerobic bacteriochlorophyll-containing bacteria, including Craurococcus (Saitoh et al., 1998), Paracraurococcus (Saitoh et al., 1998), Roseovarius (Labrenz et al., 1999), Rubrimonas (Suzuki et al., 1999a), Roseateles (Suyama et al., 1999), Roseivivax (Suzuki et al., 1999b), 'Citromicrobium' (Yurkov et al., 1999), Roseinatronobacter (Sorokin et al., 2000), Staleya (Labrenz et al., 2000), Acidisphaera (Hiraishi et al., 2000) and Roseibium (Suzuki et al., 2000), have been described.

Aerobic and chemoheterotrophic bacteriochlorophyllcontaining bacteria have been isolated from specimens from a variety of marine environments on the east and west coasts of Australia (Shiba et al., 1991). Most of these isolates have been divided into several groups on the basis of phenotypic characteristics and DNA-DNA relatedness (Nishimura et al., 1994). On the basis of phenotypic characteristics and phylogenetic considerations, we have previously proposed three novel genera, Rubrimonas, Roseivivax and Roseibium, for three groups of those isolates

Published online ahead of print on 13 October 2005 as DOI 10.1099/ ijs.0.02094-0.

The GenBank/EMBL/DDBJ accession number for the 16S rRNA gene sequence of strain $\mathrm{OCh} 323^{\top}$ is $\mathrm{AB} 061273$.
(Suzuki et al., 1999a, b, 2000). The genera Rubrimonas and Roseivivax belong to the $\alpha-3$ group, while the genus Roseibium belongs to the $\alpha-2$ group of the Proteobacteria.

In the present study, the phenotypic characteristics and the phylogeny of strain OCh $323^{\mathrm{T}}$, which has not previously been included in any group of these isolates, were investigated. On the basis of the results of these investigations, a novel genus and novel species are proposed.

Strain OCh $323^{\mathrm{T}}$ was previously isolated from sand at Monkey Mia, Shark Bay, located on the west coast of Australia, by Shiba et al. (1991). The strain was cultivated on PPES-II medium (Taga, 1968) at $27^{\circ} \mathrm{C}$. The $\mathrm{pH}$ was adjusted to $7 \cdot 8$ with $10 \% \mathrm{NaOH}$. Colonies of strain OCh $323^{\mathrm{T}}$ were circular, smooth, convex, entire, glistening, opaque and pink. Cells were stained with $1 \%(\mathrm{w} / \mathrm{v})$ aqueous uranyl acetate and examined under a JEOL model JEM-1200 EX electron microscope at an accelerating voltage of $80 \mathrm{kV}$. Cells were Gram-negative, non-motile rods (with one or both cell poles narrower) and of variable length (Fig. 1). Cell growth appeared to be monopolar, since one cell end was usually narrower and shorter than the other, possibly indicating a budding process (Hirsch, 1974). Cells of strain OCh $323^{\mathrm{T}}$ were $0 \cdot 5-0 \cdot 8 \times 1 \cdot 6-10 \cdot 0 \mu \mathrm{m}$.

Physiological and biochemical characteristics were examined according to the methods of Shiba \& Simidu (1982). Acid production from D-fructose, D-glucose and lactose was 


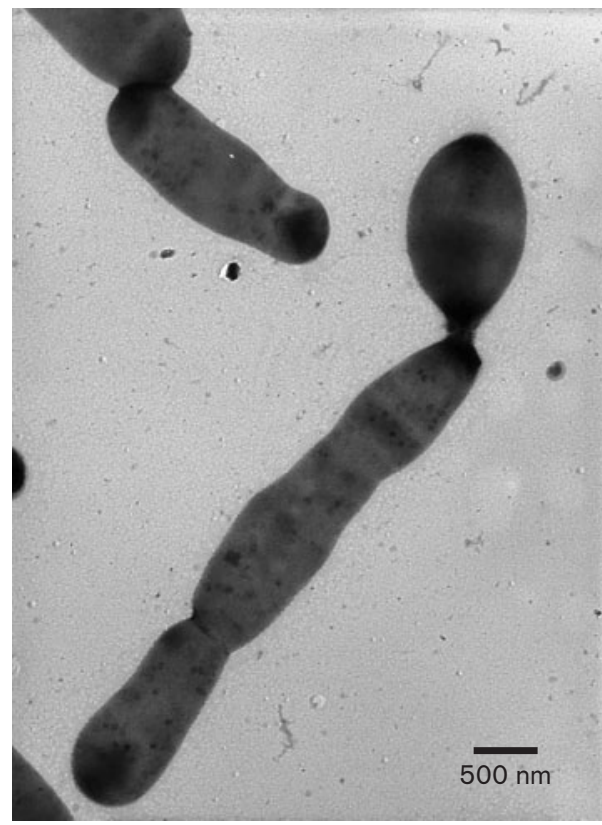

Fig. 1. Electron micrograph of negatively stained cells of strain OCh $323^{\top}$. Bar, $500 \mathrm{~nm}$.

tested on ZOF medium (Lemos et al., 1985) supplemented with a $1 \%(\mathrm{w} / \mathrm{v})$ carbohydrate source.

Strain OCh $323^{\mathrm{T}}$ grew chemoheterotrophically under aerobic conditions but could not grow phototrophically under anaerobic conditions in the light. Optimum growth occurred at $\mathrm{pH} 7 \cdot 5-8 \cdot 0$ and at $27-30{ }^{\circ} \mathrm{C}$. The strain required $\mathrm{NaCl}$, with growth occurring in $0 \cdot 5-7 \cdot 5 \% \mathrm{NaCl}$. The biochemical and physiological characteristics of strain OCh $323^{\mathrm{T}}$ are given in Table 1.

Cells were washed and sonicated for $3 \mathrm{~min}$ in $30 \mathrm{mM}$ Tris/ $\mathrm{HCl}(\mathrm{pH} \mathrm{7 \cdot 5)}$. The absorption spectrum of cell extracts was recorded with a Shimadzu UV-VIS recording spectrophotometer (model UV-160). Ultrasonically disrupted cells in buffer had absorption peaks in the near-infrared region at 879 and $800 \mathrm{~nm}$ (Fig. 2), indicating the presence of bacteriochlorophyll $a$ in light-harvesting complex I and the photochemical reaction centre.

Strain OCh $323^{\mathrm{T}}$ was grown in PPES-II broth at $27^{\circ} \mathrm{C}$ with shaking. Cells were washed with distilled water and freezedried. A $100 \mathrm{mg}$ portion of lyophilized cells was methylated with $3 \mathrm{ml} 5 \%(\mathrm{v} / \mathrm{v}) \mathrm{HCl} / \mathrm{methanol}$ at $100{ }^{\circ} \mathrm{C}$ for $3 \mathrm{~h}$. Fatty acid methyl esters were extracted with hexane three times. The hexane fraction was washed with distilled water, dehydrated with anhydrous $\mathrm{Na}_{2} \mathrm{SO}_{4}$ and then concentrated by using a rotary evaporator. Hydroxylated fatty acid methyl esters were separated from non-polar fatty acid methyl esters by TLC (silica gel $60 \mathrm{~F}_{254}$; Merck) using hexane/ diethylether $(85: 15, \mathrm{v} / \mathrm{v})$ as the developing solvent. The spots were visualized by spraying with $0.02 \%(\mathrm{w} / \mathrm{v})$
Table 1. Comparative physiological and biochemical characteristics of aerobic, chemoheterotrophic, bacteriochlorophyllcontaining bacteria

Strains: 1, strain OCh $323^{\mathrm{T}} ; 2$, Roseivivax halodurans OCh $239^{\mathrm{T}} ; 3$, Roseivivax halotolerans $\mathrm{OCh} 210^{\mathrm{T}} ; 4$, Rubrimonas cliftonensis $\mathrm{OCh}$ $317^{\mathrm{T}} ; 5$, Roseobacter litoralis OCh $149^{\mathrm{T}} ; 6$, Roseobacter denitrificans OCh $114^{\mathrm{T}}$. +, Positive; -, negative; $\mathrm{w}$, weakly positive. All strains are positive for catalase and oxidase and for growth in the presence of $0.5 \% \mathrm{NaCl}$. All strains are negative in the VogesProskauer test, for $\mathrm{H}_{2} \mathrm{~S}$ production and for the hydrolysis of alginate and starch.

\begin{tabular}{|c|c|c|c|c|c|c|}
\hline Characteristic & 1 & 2 & 3 & 4 & 5 & 6 \\
\hline Nitrate reductase & - & + & - & $\mathrm{w}$ & - & + \\
\hline Phosphatase & - & + & - & + & - & + \\
\hline Urease & + & - & + & + & - & - \\
\hline Indole production & - & + & + & + & + & + \\
\hline ONPG reaction & + & + & + & - & + & + \\
\hline \multicolumn{7}{|l|}{ Hydrolysis of: } \\
\hline Gelatin & + & - & + & - & + & + \\
\hline Tween 80 & - & - & - & - & + & + \\
\hline \multicolumn{7}{|l|}{ Utilization of: } \\
\hline D-Glucose & - & + & + & + & + & + \\
\hline Acetate & - & + & + & - & + & $\mathrm{w}$ \\
\hline Citrate & - & + & + & + & + & + \\
\hline DL-Malate & - & + & + & - & + & + \\
\hline Pyruvate & - & + & + & + & + & + \\
\hline Succinate & - & + & + & - & + & + \\
\hline Ethanol & - & - & - & + & - & - \\
\hline \multicolumn{7}{|c|}{ Acid production from: } \\
\hline D-Fructose & - & + & $\mathrm{w}$ & + & - & $\mathrm{w}$ \\
\hline D-Glucose & - & + & $\mathrm{w}$ & + & - & - \\
\hline Lactose & - & + & - & - & - & - \\
\hline \multicolumn{7}{|c|}{ Growth in the presence of $\mathrm{NaCl}$ at: } \\
\hline $0 \%$ & - & $\mathrm{W}$ & - & - & - & - \\
\hline $7 \cdot 5 \%$ & + & + & + & + & - & - \\
\hline $10 \cdot 0 \%$ & - & + & + & - & - & - \\
\hline
\end{tabular}

$2^{\prime}, 7^{\prime}$-dichlorofluorescein ethanol solution and then scraped off the TLC plate under UV light. Hydroxylated fatty acid methyl esters were extracted with diethylether. After removal of the diethylether from the extracted solution, the sample was dissolved in a small volume of hexane. To verify the presence of cyclopropanic and unsaturated acids, they were saturated with hydrogen. The analysis was performed in a GC-8A gas chromatograph (Shimadzu) equipped with an FFS ULBON HR-1 capillary column $(0.25 \mathrm{~mm} \times 50 \mathrm{~m}$; Shinwa Chemical Industries $)$, at $170-230{ }^{\circ} \mathrm{C}$ (rate: $4{ }^{\circ} \mathrm{C} \mathrm{min}^{-1}$ ). The detector used was flame-ionized. The chromatogram was processed by using Chromatopac C-R3A (Shimadzu).

The cellular fatty acids of strain OCh $323^{\mathrm{T}}$ are described in Table 2; the major cellular fatty acid is octadecenoic acid $(18: 1)$.

The cells were suspended in saline EDTA $(0 \cdot 15 \mathrm{M} \mathrm{NaCl}$, $0 \cdot 1 \mathrm{M}$ EDTA, $\mathrm{pH} 8 \cdot 5$ ) and then lysed at $60^{\circ} \mathrm{C}$ for $10 \mathrm{~min}$ 


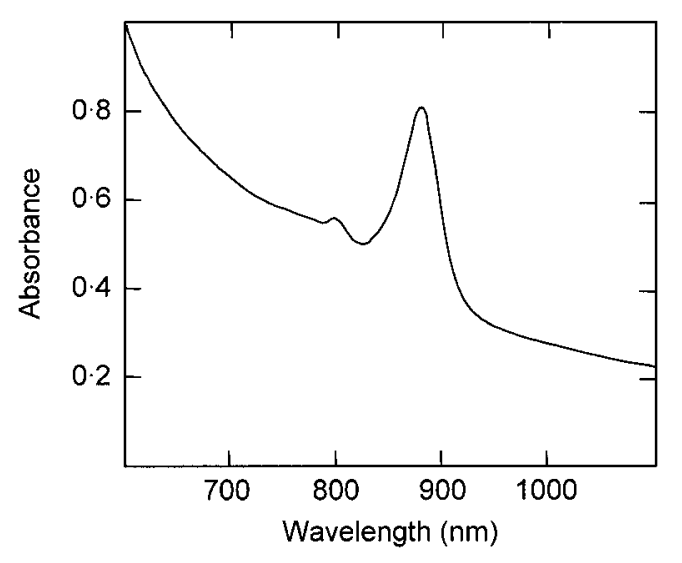

Fig. 2. Absorption spectrum of ultrasonically disrupted membrane of strain $\mathrm{OCh} 323^{\top}$, showing the presence of the photosynthetic reaction centre (minor peak at $800 \mathrm{~nm}$ ) and light-harvesting complex I (major peak at $879 \mathrm{~nm}$ ).

with $0 \cdot 5 \%$ SDS (final concentration). Chromosomal DNA was purified according to standard procedures (Sambrook et al., 1989).

The DNA G $+\mathrm{C}$ content was determined by the HPLC method (Katayama-Fujimura et al., 1984). Chromosomal DNA was denatured to the single stranded form by means of heating at $95^{\circ} \mathrm{C}$ for $5 \mathrm{~min}$. The single-stranded DNA was hydrolysed to nucleotides with P1 nuclease (DNA-GC kit; Seikagaku Kogyo) in $40 \mathrm{mM}$ sodium acetate and $2 \mathrm{mM}$ $\mathrm{ZnSO}_{4}$ (pH 5.3) at $50{ }^{\circ} \mathrm{C}$ for $2 \mathrm{~h}$. The nucleotide composition was analysed by HPLC, which was performed in a Shimadzu high-performance liquid chromatograph (model LC-6A) equipped with an octadecyl-silica column (YMC pack AQ-312, $6 \mathrm{~mm} \times 150 \mathrm{~mm}$ ), and detected at $260 \mathrm{~nm}$. The mobile phase was $10 \mathrm{mM}$ phosphate buffer $(\mathrm{pH} \mathrm{3 \cdot 5)}$. The DNA G + C content was corrected by dividing the value of the peak area of the sample nucleotide by the peak area of the standard nucleotide. The $\mathrm{G}+\mathrm{C}$ content of the DNA from strain OCh $323^{\mathrm{T}}$ was $68 \cdot 1 \mathrm{~mol} \%$.

Amplification of the 16S rRNA gene was performed on a Quick Thermo Personal QTP-1 thermocycler (Nippon Genetics) in a $100 \mu \mathrm{l}$ reaction volume, as described previously (Suzuki et al., 1999a, b). The amplified DNA fragments were purified by gel electrophoresis on $1 \%$ agarose $S$ (Nippon Gene) and recovered with glass powder, using Prep-A-Gene DNA purification systems (Bio-Rad Laboratories). Sequencing was carried out as described previously (Suzuki \& Yamasato, 1994).

The sequences of strain OCh $323^{\mathrm{T}}$ and of reference bacterial species were aligned with the CLUSTAL X program, version 1.64b (Thompson et al., 1997); the alignment was checked manually. The phylogenetic analysis was performed with PHYLIP, version 3.57c (Felsenstein, 1995). A distance matrix was calculated with DNADIST, using the Kimura
Table 2. Fatty acid compositions (\%) of whole-cell hydrolysates of aerobic, chemoheterotrophic, bacteriochlorophyllcontaining bacteria

Strains: 1, strain OCh $323^{\mathrm{T}}$; 2, Roseivivax halodurans OCh $239^{\mathrm{T}}$; 3 , Roseivivax halotolerans $\mathrm{OCh} 210^{\mathrm{T}}$; 4, Rubrimonas cliftonensis $\mathrm{OCh}$ $317^{\mathrm{T}} ; 5$, Roseobacter litoralis $\mathrm{OCh} 149^{\mathrm{T}} ; 6$, Roseobacter denitrificans OCh $114^{\mathrm{T}}$. -, Not detected; tr, trace.

\begin{tabular}{|lcccccc|}
\hline Fatty acid & $\mathbf{1}$ & $\mathbf{2}$ & $\mathbf{3}$ & $\mathbf{4}$ & $\mathbf{5}$ & $\mathbf{6}$ \\
\hline $14: 0$ & $\operatorname{tr}$ & 2 & - & $\operatorname{tr}$ & $\operatorname{tr}$ & $\operatorname{tr}$ \\
$15: 0$ & 1 & $\operatorname{tr}$ & $\operatorname{tr}$ & - & $\operatorname{tr}$ & - \\
$16: 0$ & 12 & 13 & 5 & 16 & 1 & 2 \\
$17: 0$ & 1 & 2 & 1 & $\operatorname{tr}$ & 1 & 1 \\
$18: 0$ & 8 & 7 & 4 & 2 & 1 & 1 \\
$19: 0$ & - & 15 & 10 & - & $\operatorname{tr}$ & $\operatorname{tr}$ \\
$16: 1$ & 1 & $\operatorname{tr}$ & $\operatorname{tr}$ & 2 & $\operatorname{tr}$ & 1 \\
$18: 1$ & 68 & 44 & 69 & 69 & 94 & 92 \\
cyclo $19: 0$ & 4 & - & - & - & - & - \\
$18: 2$ & $\operatorname{tr}$ & - & - & - & 2 & 1 \\
$2-$ OH $16: 0$ & 2 & - & - & - & - & - \\
$3-$ OH $14: 0$ & - & - & - & 2 & - & - \\
Unknown & 2 & 16 & 10 & 8 & 1 & 2 \\
\end{tabular}

two-parameter method, and a phylogenetic tree was reconstructed using NEIGHBOR. The stability of the clusters was ascertained by performing bootstrap analyses (1000 replications) with SEQBOOT, DNADIST, NEIGHBOR and CONSENSE.

The 16S rRNA gene sequence of strain OCh $323^{\mathrm{T}}$ was determined and aligned with other available 16S rRNA gene sequences. A comparison of the $16 \mathrm{~S}$ rRNA gene sequences, for which a phylogenetic tree was reconstructed (Fig. 3), revealed that strain OCh $323^{\mathrm{T}}$ belonged to the $\alpha-3$ group of the Proteobacteria, forming a separate line of descent. The $16 \mathrm{~S}$ rRNA gene sequence similarity values between strain OCh $323^{\mathrm{T}}$ and other strains belonging to this group were low: $91.4 \%$ for Rhodovulum sulfidophilum, $90.7 \%$ for Ruegeria algicola, $90.5 \%$ for Rhodovulum adriaticum, $90.2 \%$ for Rhodobacter sphaeroides and $90.0 \%$ for Rhodovulum iodosum.

Aerobic bacteriochlorophyll-containing, budding bacteria are known, e.g. Porphyrobacter neustonensis (Fuerst et al., 1993), Roseovarius tolerans (Labrenz et al., 1999) and Staleya guttiformis (Labrenz et al., 2000). Phylogenetically, Porphyrobacter neustonensis is located in the $\alpha-4$ group, whereas Roseovarius tolerans and S. guttiformis belong to the $\alpha-3$ group of the Proteobacteria. Strain OCh $323^{\mathrm{T}}$ is distantly related to Roseovarius tolerans and S. guttiformis. It has been demonstrated previously that phenotypic characteristics are not necessarily reflected in phylogenetic relationships; this inconsistency was also apparent in the present study.

The phylogenetic analysis supports the need for a novel genus, Roseibacterium gen. nov., to be created for strain $\mathrm{OCh}$ 


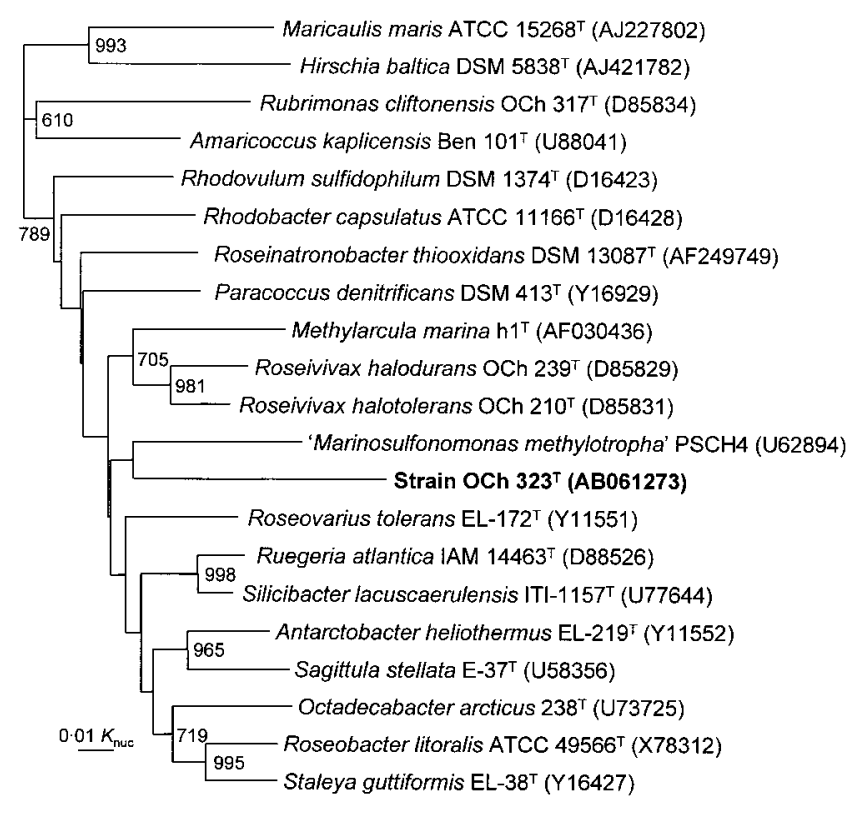

Fig. 3. Neighbour-joining phylogenetic tree derived from analysis of the 16S rRNA gene sequences of Roseibacterium elongatum OCh $323^{\top}$ and other members of the $\alpha-3$ group of the Proteobacteria. Numbers at nodes indicate levels of bootstrap support based on 1000 resamplings; only values above 500 are considered as significant and are indicated.

$323^{\mathrm{T}}$, and we propose that strain OCh $323^{\mathrm{T}}$ should be described as the type strain of Roseibacterium elongatum gen. nov., sp. nov.

\section{Description of Roseibacterium gen. nov.}

Roseibacterium (Ro.sei.bac.te' ri.um. L. adj. roseus rose, pink; Gr. neut. n. bakterion rod; N.L. neut. n. Roseibacterium pink, rod-shaped bacterium).

Cells are Gram-negative, non-motile rods that multiply by monopolar growth, i.e. by an apparent budding process. Aerobic chemoheterotrophs. Cells exhibit catalase and oxidase activities. Bacteriochlorophyll $a$ is synthesized under aerobic conditions. The major cellular fatty acid is octadecenoic acid (18:1). The genus Roseibacterium belongs to the $\alpha-3$ group of the Proteobacteria. The type species is Roseibacterium elongatum.

\section{Description of Roseibacterium elongatum sp. nov.}

Roseibacterium elongatum (e.lon.ga'tum. L. part. neut. adj. elongatum elongated, stretched out).

Colonies are circular, smooth, convex, entire, glistening, opaque and pink. Cells are $0.5-0.8 \times 1.6-10.0 \mu \mathrm{m}$. Optimum growth occurs at $\mathrm{pH} 7 \cdot 5-8 \cdot 0$ and at $27-30{ }^{\circ} \mathrm{C}$. Growth occurs in the presence of $0 \cdot 5-7 \cdot 5 \% \mathrm{NaCl}$, but not in the absence of $\mathrm{NaCl}$. Cells exhibit urease activity, but not nitrate reductase or phosphatase activities. Negative in the Voges-Proskauer test. The ONPG reaction is positive. Cells do not produce indole or $\mathrm{H}_{2} \mathrm{~S}$. Gelatin is hydrolysed, but alginate, starch and Tween 80 are not. Cells do not utilize Dglucose, acetate, citrate, DL-malate, pyruvate, succinate or ethanol. Acid is not produced from D-fructose, D-glucose or lactose. The absorption spectrum of ultrasonically disrupted cells in the near-infrared region has maxima at $879 \mathrm{~nm}$ and $800 \mathrm{~nm}$. The $\mathrm{G}+\mathrm{C}$ content of the DNA is $68 \cdot 1 \mathrm{~mol} \%$.

The type strain, strain OCh $323^{\mathrm{T}}\left(=\mathrm{JCM} 11220^{\mathrm{T}}=\mathrm{CIP}\right.$ $107377^{\mathrm{T}}$ ), was isolated from sand at Monkey Mia, Shark Bay, located on the west coast of Australia.

\section{Acknowledgements}

We are grateful to Dr Tsuneo Shiba (National Fisheries University, Shimonoseki, Japan) for providing the bacterial strains.

\section{References}

Felsenstein, J. (1995). PHYLIP (phylogeny inference package), version 3.57c. Distributed by the author. Department of Genome Sciences, University of Washington, Seattle, USA.

Fuerst, J. A., Hawkins, J. A., Holmes, A., Sly, L. I., Moore, C. J. \& Stackebrandt, E. (1993). Porphyrobacter neustonensis gen. nov., sp. nov., an aerobic bacteriochlorophyll-synthesizing budding bacterium from fresh water. Int J Syst Bacteriol 43, 125-134.

Hiraishi, A., Matsuzawa, Y., Kanbe, T. \& Wakao, N. (2000). Acidisphaera rubrifaciens gen. nov., sp. nov., an aerobic bacteriochlorophyll-containing bacterium isolated from acidic environments. Int J Syst Evol Microbiol 50, 1539-1546.

Hirsch, P. (1974). Budding bacteria. Annu Rev Microbiol 28, 391-444.

Katayama-Fujimura, Y., Komatsu, Y., Kuraishi, H. \& Kaneko, T. (1984). Estimation of DNA base composition by high performance liquid chromatography of its nuclease P1 hydrolysate. Agric Biol Chem 48, 3169-3172.

Labrenz, M., Collins, M. D., Lawson, P. A., Tindall, B. J., Schumann, P. \& Hirsch, P. (1999). Roseovarius tolerans gen. nov., sp. nov., a budding bacterium with variable bacteriochlorophyll $a$ production from hypersaline Ekho Lake. Int J Syst Bacteriol 49, 137-147.

Labrenz, M., Tindall, B. J., Lawson, P. A., Collins, M. D., Schumann, P. \& Hirsch, P. (2000). Staleya guttiformis gen. nov., sp. nov. and Sulfitobacter brevis sp. nov., $\alpha$-3-Proteobacteria from hypersaline, heliothermal and meromictic antarctic Ekho Lake. Int J Syst Evol Microbiol 50, 303-313.

Lemos, M. L., Toranzo, A. E. \& Barja, J. L. (1985). Modified medium for the oxidation-fermentation test in the identification of marine bacteria. Appl Environ Microbiol 49, 1541-1543.

Nishimura, Y., Muroga, Y., Saito, S., Shiba, T., Takamiya, K. \& Shioi, Y. (1994). DNA relatedness and chemotaxonomic feature of aerobic bacteriochlorophyll-containing bacteria isolated from coasts of Australia. J Gen Appl Microbiol 40, 287-296.

Saitoh, S., Suzuki, T. \& Nishimura, Y. (1998). Proposal of Craurococcus roseus gen. nov., sp. nov. and Paracraurococcus ruber gen. nov., sp. nov., novel aerobic bacteriochlorophyll $a$-containing bacteria from soil. Int J Syst Bacteriol 48, 1043-1047. 
Sambrook, J., Fritsch, E. F. \& Maniatis, T. (1989). Molecular Cloning: a Laboratory Manual, 2nd edn. Cold Spring Harbor, NY: Cold Spring Harbor Laboratory.

Sato, K. (1978). Bacteriochlorophyll formation by facultative methylotrophs, Protaminobacter ruber and Pseudomonas AM 1. FEBS Lett 85, 207-210.

Shiba, T. \& Simidu, U. (1982). Erythrobacter longus gen. nov., sp. nov., an aerobic bacterium which contains bacteriochlorophyll $a$. Int J Syst Bacteriol 32, 211-217.

Shiba, T., Shioi, Y., Takamiya, K., Sutton, D. C. \& Wilkinson, C. R. (1991). Distribution and physiology of aerobic bacteria containing bacteriochlorophyll $a$ on the east and west coasts of Australia. Appl Environ Microbiol 57, 295-300.

Sorokin, D. Y., Tourova, T. P., Kuznetsov, B. B., Bryantseva, I. A. \& Gorlenko, V. M. (2000). Roseinatronobacter thiooxidans gen. nov., sp. nov., a new alkaliphilic aerobic bacteriochlorophyll $a$-containing bacterium isolated from a soda lake. Microbiology (English translation of Mikrobiologiia) 69, 75-82.

Suyama, T., Shigematsu, T., Takaichi, S., Nodasaka, Y., Fujikawa, S., Hosoya, H., Tokiwa, Y., Kanagawa, T. \& Hanada, S. (1999). Roseateles depolymerans gen. nov., sp. nov., a new bacteriochlorophyll $a$-containing obligate aerobe belonging to the $\beta$-subclass of the Proteobacteria. Int J Syst Bacteriol 49, 449-457.

Suzuki, T. \& Yamasato, K. (1994). Phylogeny of spore-forming lactic acid bacteria based on $16 \mathrm{~S}$ rRNA gene sequences. FEMS Microbiol Lett 115, 13-18.
Suzuki, T., Muroga, Y., Takahama, M., Shiba, T. \& Nishimura, Y. (1999a). Rubrimonas cliftonensis gen. nov., sp. nov., an aerobic bacteriochlorophyll-containing bacterium isolated from a saline lake. Int J Syst Bacteriol 49, 201-205.

Suzuki, T., Muroga, Y., Takahama, M. \& Nishimura, Y. (1999b). Roseivivax halodurans gen. nov., sp. nov. and Roseivivax halotolerans sp. nov., aerobic bacteriochlorophyll-containing bacteria isolated from a saline lake. Int J Syst Bacteriol 49, 629-634.

Suzuki, T., Muroga, Y., Takahama, M. \& Nishimura, Y. (2000). Roseibium denhamense gen. nov., sp. nov. and Roseibium hamelinense sp. nov., aerobic bacteriochlorophyll-containing bacteria isolated from the east and west coasts of Australia. Int J Syst Evol Microbiol 50, 2151-2156.

Taga, N. (1968). Some ecological aspects of marine bacteria in the Kuroshio current. Bull Misaki Mar Biol Inst Kyoto Univ 12, 56-76.

Thompson, J. D., Gibson, T. J., Plewniak, F., Jeanmougin, F. \& Higgins, D. G. (1997). The CLUSTAL_X Windows interface: flexible strategies for multiple sequence alignment aided by quality analysis tools. Nucleic Acids Res 25, 4876-4882.

Yurkov, V. V. \& Beatty, J. T. (1998). Aerobic anoxygenic phototrophic bacteria. Microbiol Mol Biol Rev 62, 695-724.

Yurkov, V. V., Krieger, S., Stackebrandt, E. \& Beatty, J. T. (1999). Citromicrobium bathyomarinum, a novel aerobic bacterium isolated from deep-sea hydrothermal vent plume waters that contains photosynthetic pigment-protein complexes. J Bacteriol 181, 4517-4525. 